\title{
Trilobites from the Rickard Hill facies of the Saugerties Member of the Schoharie Formation, eastern New York (upper Emsian and Lower Devonian): a case study in taphonomy and sequence stratigraphy from glacial erratics
}

\author{
Martin A. Becker, ${ }^{1 *}$ Rebecca B. Chamberlain, ${ }^{2}$ Harry M. Maisch IV, ${ }^{3}$ Alex BartholomeW ${ }^{4}$, \\ AND John A. Chamberlain JR..$^{3-5}$ \\ 1. Department of Environmental Science, William Paterson University, 300 Pompton Road, Wayne, New Jersey 07470, USA \\ 2. Department of Biology, College of Staten Island, Staten Island, New York 10314, USA \\ 3. Doctoral Programs in Earth and Environmental Sciences, City University of New York Graduate Center, \\ New York, New York 10016, USA \\ 4. Geology Department, SUNY, New Paltz, New York 12561, USA \\ 5. Department of Earth and Environmental Sciences, Brooklyn College, 2900 Bedford Avenue, Brooklyn, New York 11210, USA \\ ${ }^{*}$ Corresponding author <beckerm2@wpunj.edu $>$
}

Date received: 22 December 2016 gate accepted: 16 May 2017

\begin{abstract}
Glacial erratics belonging to the Rickard Hill facies (RHf) of the Saugerties Member of the Schoharie Formation (upper Emsian: Lower Devonian) occur scattered throughout the Piedmont of northern New Jersey and Lower Hudson Valley of New York. These RHf glacial erratics contain an assemblage of trilobites belonging to: Anchiopella anchiops, Burtonops cristatus, Calymene platys, Terataspis grandis, cf. Trypaulites sp. and cf. Coniproetus sp. This RHf glacial erratic trilobite assemblage consists predominantly of disarticulated cephala and pygidia that were originally preserved as part of a localized, third-order eustatic sea level lag deposit in the area of the present day Helderberg Mountains region of New York State and subsequently transported in glacially plucked blocks by the Hudson-Champlain Lobe of the Laurentide Ice Sheet southward into New Jersey. Physical and chemical weathering during glacial erosion, transportation and deposition of the RHf glacial erratics has revealed some anatomical features of these trilobites in high detail along with other invertebrates. This unique sequence of weathering reveals additional characteristics that bear upon issues of bathymetric controls on upper Schoharie Formation lithology, trilobite faunal abundance and taphonomy during the upper Emsian (Lower Devonian) of eastern New York State.
\end{abstract}

\section{RÉSUMÉ}

Des éléments erratiques glaciaires faisant partie du faciès de la Rickard Hill (RHf) du Membre Saugerties de la Formation de Schoharie (Emsien supérieur: Dévonien inférieur) sont présents de façon éparse partout à l'intérieur du Piedmont dans le nord du New Jersey et la vallée du cours inférieur de l'Hudson de l'État de New York. Ces éléments renferment un assemblage de trilobites faisant partie des Anchiopella anchiops, Burtonops cristatus, Calymene platys et Terataspis grandis, comparables à l'espèce des Trypaulites et à l'espèce des Coniproetus. Cet assemblage de trilobites des éléments erratiques glaciaires du RHf est principalement constitué de céphalums et de pygidiums ayant originalement été conservés au sein d'une charge de fond localisée, au niveau marin eustatique de troisième ordre, dans le secteur de la région des monts Helderberg actuels de l'État de New York et subséquemment transportés dans des blocs grainelés par l'impact glaciaire du compartiment Hudson-Champlain de l'Inlandsis laurentidien en direction sud vers le New Jersey. Laltération atmosphérique physique et chimique survenue durant l'érosion glaciaire, le transport et la sédimentation des éléments erratiques glaciaires du RHf ont révélé certaines particularités anatomiques des trilobites de façon très détaillée ainsi que d’autres invertébrés. Cette séquence unique d’altération atmosphérique révèle d’autres caractéristiques témoignant d'un contrôle bathymétrique sur la lithologie de la partie supérieure de la Formation de Schoharie, d'une abondance de la faune de trilobites et de la taphonomie durant la période de l'Emsien supérieur (du Dévonien inférieur) dans l'est de l'État de New York.

[Traduit par la redaction] 


\section{INTRODUCTION}

Over a century ago, the first occurrence of trilobite fossils in New Jersey glacial erratics was identified approximately $1.5 \mathrm{~km}$ north of the city of Paterson by Whitfield and Parsons (1897). Their study described hypostomes and other disarticulated skeletal elements belonging to Terataspis grandis (Hall 1861) from glacial erratics of the Schoharie Grit. Since that time, reports of trilobites in New Jersey have been based almost exclusively on in-situ faunas collected in the northwesternmost part of the state and immediately adjacent outcrops in southern New York and eastern Pennsylvania (e.g., Weller 1903; Shimer 1905; Epstein et al. 1967; Couri et al. 2011).

Recently, an assemblage of fossiliferous glacial erratics containing trilobites was discovered scattered across the northern New Jersey Piedmont and Lower Hudson Valley of New York (Becker and Bartholomew 2013; Becker et al. 2016). The occurrence of these trilobite-bearing glacial erratics was traced from outcrops of the Rickard Hill facies (RHf; see below) of the Saugerties Member of the Schoharie Formation (upper Emsian: Lower Devonian) near Clarksville, New York, to the northern New Jersey Piedmont (Fig. 1). The locations along this erratic trail support a nearly due north to south Laurentide Ice Sheet advance and retreat in this part of eastern New York and northern New Jersey, as shown on earlier surficial geologic maps by Stone et al. (2002) and Stanford (2003).

In this report we describe the occurrence of 24 trilobite specimens belonging to six different species discovered in RHf glacial erratics since completion of the original account by Becker and Bartholomew (2013). The six forms are: Anchiopella anchiops (Woodward 1873), Burtonops cristatus (Hall 1861), Calymene platys (Green 1832), Terataspis grandis, cf. Trypaulites sp. and cf. Coniproetus sp. Physical and chemical weathering during glacial erosion, transportation and deposition of RHf glacial erratics reveals features of these trilobites and other invertebrate fossils not normally seen in outcrops of the Schoharie Formation. These features provide an opportunity to assess the role of localized bathymetry and topography on trilobite taphonomy during third-order eustatic sea-level cyclicity in the upper Schoharie Formation and RHf (upper Emsian: Lower Devonian) of eastern New York State.

\section{RICKARD HILL FACIES OF THE SCHOHARIE FORMATION: GLACIAL ERRATIC SOURCE REGION AND RECOVERY LOCATIONS}

In outcrops, the overall thickness, lithology and fauna of the Schoharie Formation undergo considerable variation between Port Jervis and Cherry Valley, New York. The members of the Schoharie Formation are, from oldest to youngest, Gumaer Island, Aquetuck and Saugerties (Ver Straeten and Brett 2006) (Fig. 2). Exposures of the RHf of the Saugerties Member of the Schoharie Formation identified in Becker and Bartholomew (2013) occur as a narrow outcrop belt centered near the town of Clarksville (Figs. 1-2). This localized facies belt was originally designated as the Rickard Hill Member of the Schoharie Formation by Johnsen and Southard (1962) and is characterized by a sandy limestone to calcareous sandstone containing brachiopods and prominent cephalopods. Johnsen and Southard (1962) indicated that the Rickard Hill Member ranged in thickness from a thin feather edge near East Springfield to a maximum of $2 \mathrm{~m}$ in Schoharie and western Albany counties. More recent study by Ver Straeten and Brett (2006) identified the Rickard Hill Member as a locally developed sandstone facies and recommended its abandonment as a member and its reassignment to the Saugerties Member. We follow Ver Straeten and Brett (2006) in referring to this unit as the Rickard Hill facies (RHf) of the Saugerties Member of the Schoharie Formation.

According to Becker and Bartholomew (2013), the RHf consists of individual beds that range in thickness from a few centimeters to approximately one meter. These beds consist of bluish to medium-gray, exceedingly hard and well-cemented sandy limestone with exterior surfaces weathered light tan to yellow. The contact of the RHf of the Saugerties Member in the Clarksville region with the overlying Edgecliff Member of the Onondaga Formation is sharp and erosional. At this contact there is a distinct lithology change from a highly fossiliferous, pyritic and sandy limestone of the RHf to a finer-grained gray limestone with occasional crinoid and coral fossils of the Edgecliff Member. This striking change in lithology and fossil concentration across the contact horizon is atypical of that seen in other outcrop exposures in eastern New York where the transition between these formations is gradual (e.g., Johnsen and Southard 1962; Brett and Ver Straeten 1994; Ver Straeten 1996; 2007). Although some beds are poorly fossiliferous, much of the RHf contains abundant invertebrate fossils preserved as casts and molds, with the notable preservation of large orthoconic and coiled cephalopods.

Numerous Paleozoic thrust faults throughout Clarksville have produced extensive jointing within the RHf, which can be also observed within local cave systems (Cooper and Mylroie 2015). Along Route 85 in Clarksville, an excellent outcrop exposure of the RHf occurs, as well as exposures of the Gumaer Island, Aquetuck and Saugerties members of the Schoharie Formation (Fig. 2). Ver Straeten (1996; 2007) provided member assignments, lithologic descriptions, measured sections and sequence stratigraphic interpretations for this exposure. A thrust fault seen in this outcrop offsets these three members and has generated drag folding of the RHf, as seen in Fig. 2. We consider that such thrust faulting has facilitated glacial plucking of the RHf and accelerated physical and chemical erosion of the RHf glacial erratics during transport within the HudsonChamplain Lobe of the Laurentide Ice Sheet.

RHfglacial erratics containing the trilobites and described 


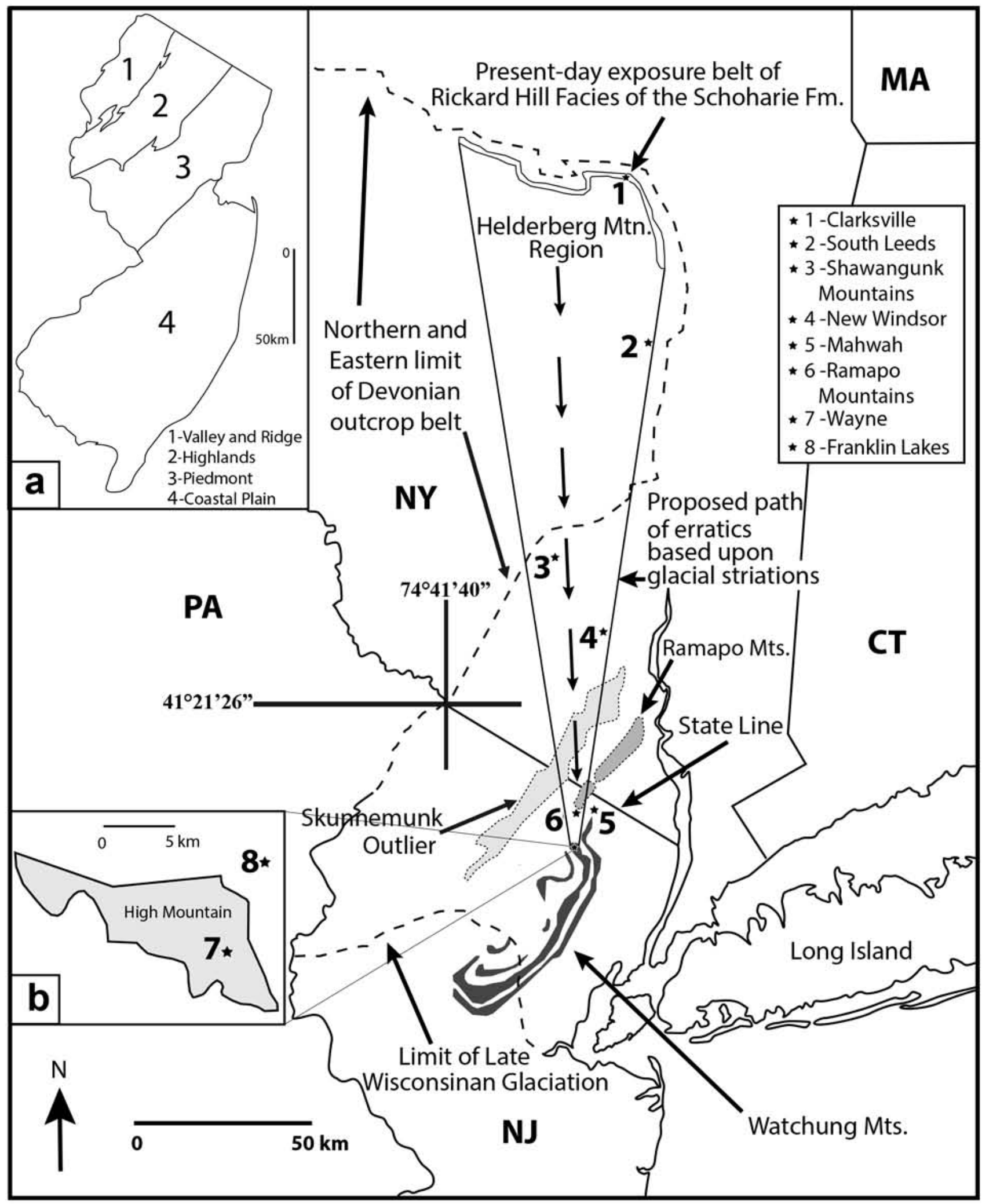

Figure 1. Locality map of the Piedmont and Lower Hudson Valley with proposed path of glacial transport from the Rickard Hill facies (RHf) of the Schoharie Formation, Helderberg Mountains Region, New York. $\left({ }^{\star} 1\right)$ RHf exposure belt; $\left({ }^{\star} 2{ }^{\star} 8\right)$ fossiliferous erratics described in Becker and Bartholomew (2013); Becker et al. (2016) and this report. Inset maps: (a) physiographic provinces of New Jersey and (b) High Mountain region. Note: limit of Wisconsin Glaciation, Skunnemunk Mountains, Ramapo Mountains. 

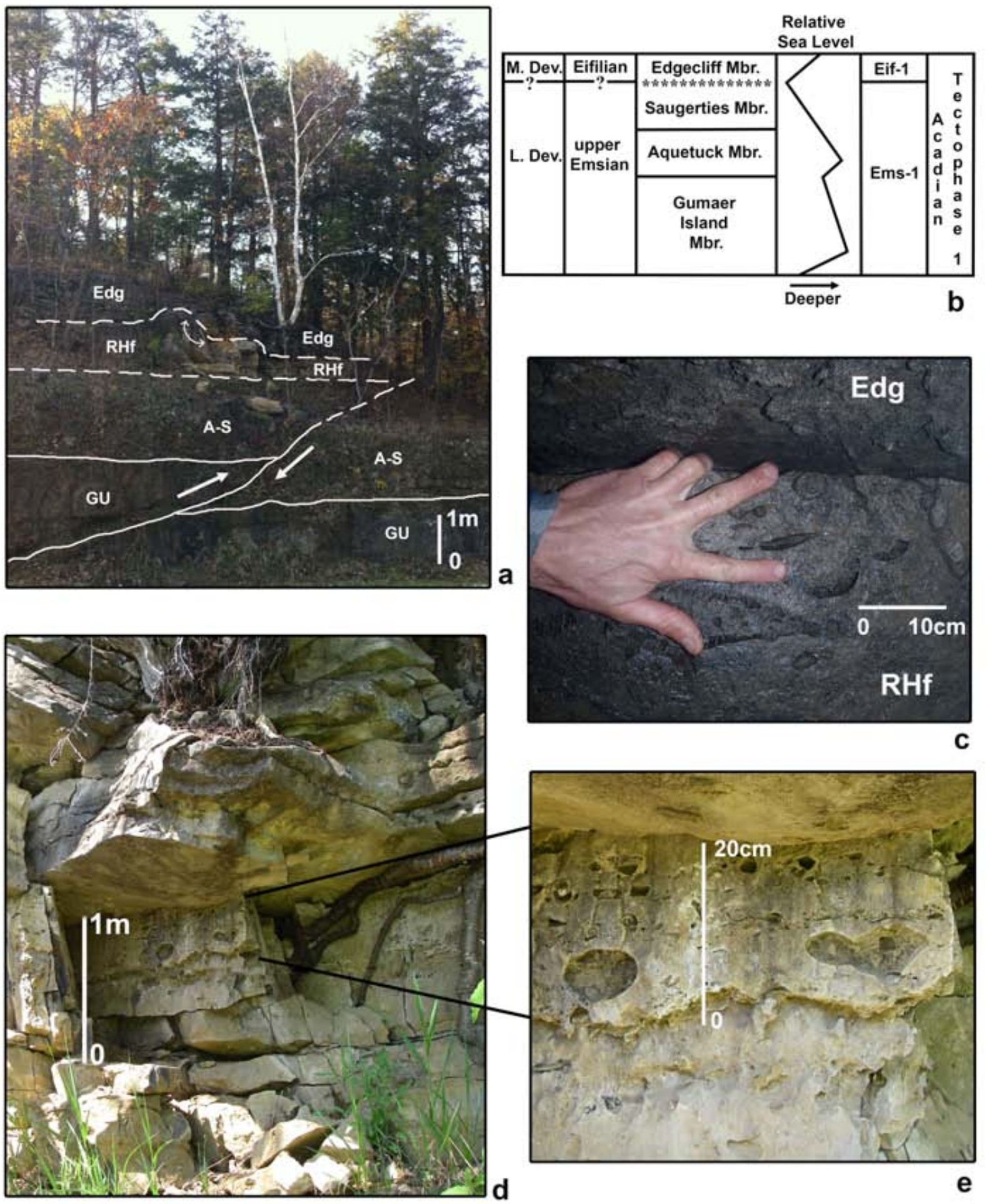

Figure 2. Stratigraphic column with sequence stratigraphy, outcrop exposures and thrust faults in the Rickard Hill facies (RHf), Gumaer Island, Aquetuck and Saugerties members of the Schoharie Formation, Clarksville, New York. (a) Modified from Ver Straeten (2007, fig. 19); (b) Roadcut exposure along Route 85, Clarksville, New York. Note that RHf is dipping to the northwest and drag folded as the result of thrust faulting. Also see Ver Straeten (1996; 2007); (c) Contact and thrust fault between the RHf and Edgecliff Member, Brinley Sump, Clarksville Cave, Clarksville, New York; (d-e) Close-ups of the RHf along Route 85, Clarksville, New York. Note sandy limestone lithology as well as cast and mold preservation of invertebrate fossils. Abbreviations: RHf-Rickard Hill facies; GU- Gumaer Island Member; A-S-Aquetuck and Saugerties members. 
in this report were recovered from ground moraines and till deposits within the northern New Jersey Piedmont and Lower Hudson Valley. In these areas, RHf erratics are uncommon and occur scattered among other glacial erratics that typically represent metamorphic and intrusive igneous rocks (Fig. 3). Many of the RHf erratics retain the blocky, jointed bedding seen in outcrop exposures at Clarksville, while others show rounding typical of boulders found in regional ground moraines (Fig. 3). Additionally,

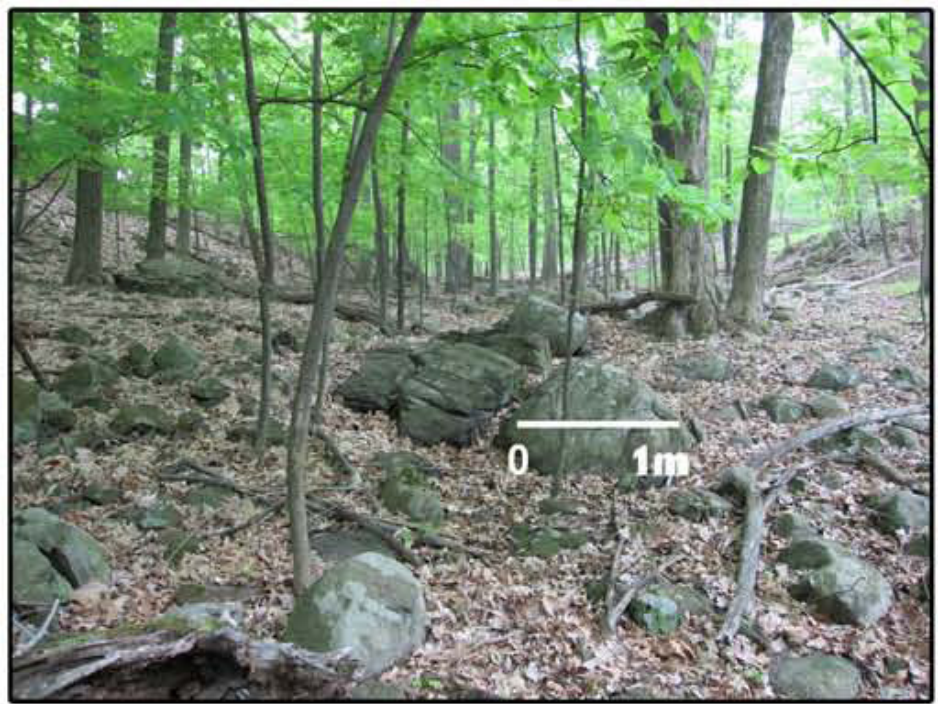

the exterior surfaces of both blocky and rounded erratics exhibit the same weathered light tan to yellow surfaces and characteristic cross-sections of fossil casts and molds present on weathered RHf surfaces at the Clarksville source exposure.

Although some transported RHf blocks may have been weathered prior to glacial plucking, we infer that slow, acidic dissolution of the exceedingly hard and well-cemented sandy limestone during glacial plucking and transport has

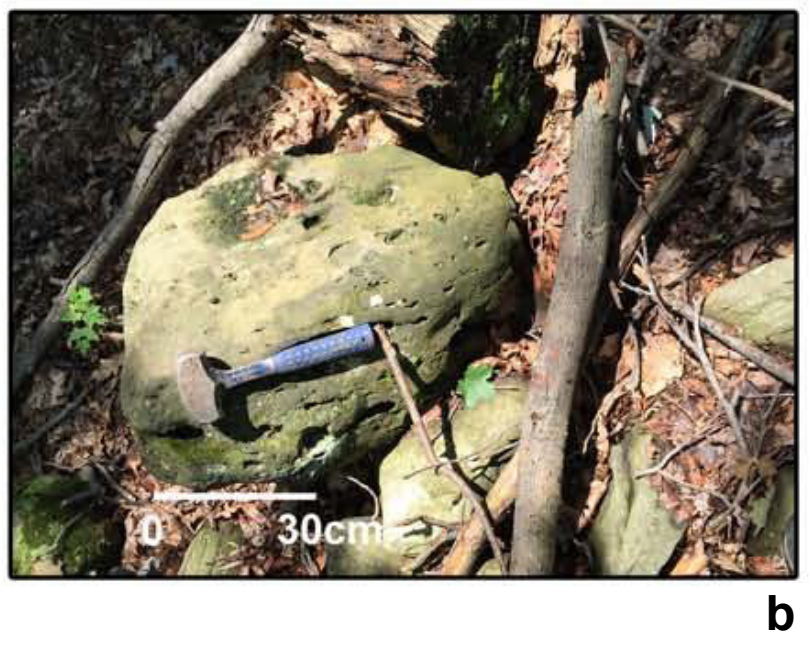

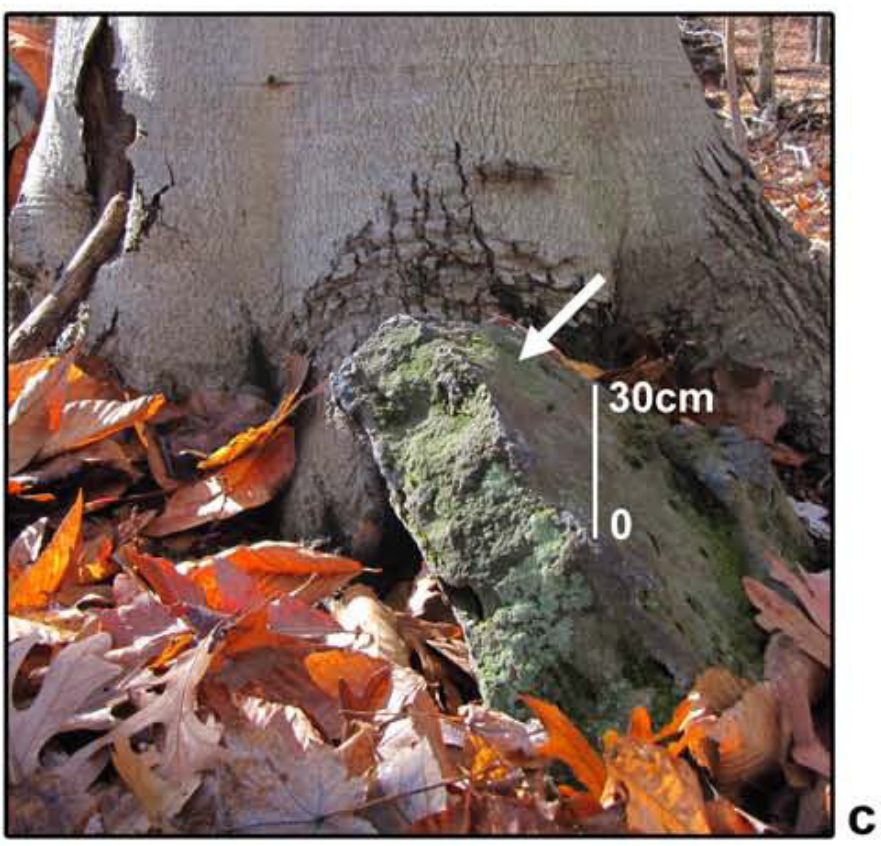

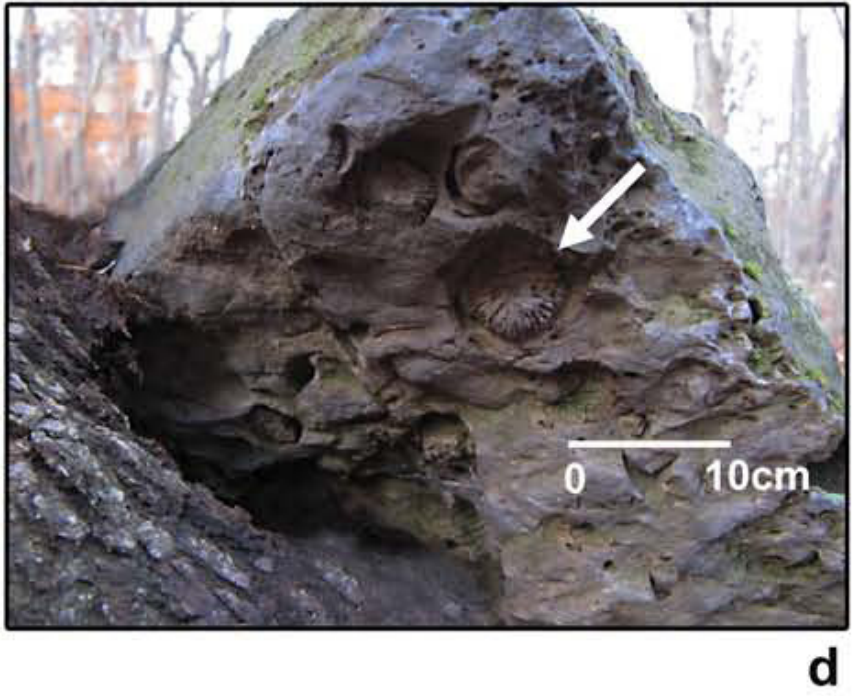

Figure 3. Glacial erratics of the RHf as seen in the northern New Jersey Piedmont, Passaic County, New Jersey. (a) Ground moraine composed mainly of intrusive igneous and metamorphic erratics. (b) Glacial erratic of the RHf found in ground moraine seen in (a); note similarities of fossil casts and molds as well as exterior surface weathering to that seen in Clarksville, New York region. (c) American beech tree growing over RHf glacial erratic. (d) The bark of the red oak tree can be seen in the bottom of the photograph and growing around the RHf erratic. Note rugose coral in cross-section indicated by arrow. 
resulted in extensive solutioning of the interior of many boulders, particularly along fossiliferous bedding planes. This has caused the interiors of many boulders to take on the color and fossil preservation features typical of the weathered surfaces. The original bluish to medium-gray, sandy limestone character of the unweathered rock seen in outcrop is not apparent in many of the glacially transported erratics. Additional discussion of the Clarksville source area and the Lower Hudson Valley and northern New Jersey Piedmont recovery locations is available in Becker and Bartholomew (2013) and Becker et al. (2016).

\section{FIELD TECHNIQUES AND GENERAL DESCRIPTION OF THE ASSEMBLAGE}

Trilobites contained in the RHf glacial erratics were collected by hiking a series of transects across the northern New Jersey Piedmont and Lower Hudson Valley, New York, recovery locations with specific focus on larger boulders concentrated in ground moraines and till deposits. All fossils identified and discussed in this study were collected by splitting RHf glacial erratics along fossiliferous bedding plains with standard field tools. Trilobite specimens featured in Figs. 4-9 were removed from the fossiliferous bedding plains of glacial erratics, some erratics weighing as much as $100 \mathrm{~kg}$ or more, for laboratory study using standard binocular microscope techniques. Currently, RHf glacial erratics have been recovered in the towns of South Leeds, New Windsor, Mahwah, Franklin Lakes and Wayne as well as the Shawangunk and Ramapo Mountains, (Fig. 1). Locations of individual RHf glacial erratics were documented by a handheld GPS unit. Trilobite specimens discussed here are reposited in the geologic collections of the Department of Environmental Science, William Paterson University.

Based on the features included in Table 1, we have determined that the RHf glacial erratic trilobite assemblage consists of the following species: Anchiopella anchiops, Burtonops cristatus, Calymene platys, Terataspis grandis, cf. Trypaulites sp. and cf. Coniproetus sp. In their comprehensive analysis of trilobites from New York, it is notable that Whiteley et al. (2002) indicated that most species found in the Schoharie Formation are known only from incomplete specimens of cephala and pygidia. Similar conditions of preservation occur in this study, with all 24 specimens included in Figs. 4-9 being incomplete, but preserving enough anatomical details to permit higherorder taxonomic classification. The majority of the bestpreserved specimens included in Figs. 4-9 are chemically weathered, sandy limestone casts recovered from the interiors of RHf glacial erratics. A complete list of trilobite species currently known from the Schoharie Formation in New York is included in Whiteley et al. (2002).

Examples of diagnostic anatomical features seen in trilobites from RHf glacial erratics include: (1) a large terminal spine in Anchiopella anchiops (Fig. 5d); (2) 14 rows of eye lenses in Burtonops cristatus, (Fig. 4i); (3) extensive, spinose and tubercled ornamentation of the cephalon in Terataspis grandis (Fig. 6a); (4) a forward expanding glabella in Calymene platys, (Fig. 7a); (5) flat pleural ribs in cf. Trypaulites sp.; and (6) a distinct pygidial border in cf. Coniproetus sp. (Fig. 8b). Three examples of the more delicate thorax regions are also preserved in the RHf glacial erratics (Figs. 7a-b, 9f). The majority of cephala and pygidia seen in Figs. 4-9 were recovered from different RHf glacial erratics and therefore are unlikely to represent the same individuals. An exception is the pygidium and pygidial spines of Terataspis grandis seen in Fig. $6 \mathrm{c}-\mathrm{d}$, in which the two specimens were not articulated, but recovered adjacent to one another on the same RHf glacial erratic.

\section{TAPHONOMY OF THE RICKARD HILL FACIES GLA- CIAL ERRATIC TRILOBITES}

The concentration and preservation of trilobites and invertebrate fossils in the RHf, as seen in outcrop and glacial erratics, are unique, unlike those of any identified outside the RHf in the Schoharie Formation throughout its outcrop belt, including well-known Schoharie bedrock localities such as Kingston, Highland Mills and Port Jervis. This outcrop belt extends over $300 \mathrm{~km}$ between central and eastern New York, northeastern Pennsylvania and northwestern New Jersey (Johnsen and Southard 1962; Ver Straeten 2007). In addition to the six species of trilobites discussed in this report, as many as 20 species of brachiopods and 15 species of cephalopods have also been identified from RHf glacial erratics (Younger et al. 2016; Brembs et al. 2015). It is notable that the large cephalopods seen in both RHf outcrop and RHf glacial erratics have not been identified or described from the numerous bioherms found in the Edgecliff Member and along the contact between the Schoharie and Onondaga Formations in eastern New York (e.g., Oliver 1956). It is this distinctive occurrence of cephalopods that not only identifies the source for the glacial erratics, but also reflects a particular set of localized taphonomic conditions within the RHf of the upper Schoharie Formation in the area surrounding Clarksville.

We interpret the taphonomic conditions found in the RHf to be analogous with those seen in some Middle Devonian trilobite assemblages from the Hamilton Group of western New York by Speyer and Brett (1986). Speyer and Brett (1986) defined four facies, or taphofacies, based on diagnostic taphonomic traits of trilobite assemblages and associated invertebrate fossils. In their taphofacies 1A, key features also seen in the RHf glacial erratic trilobite assemblage include: (1) almost entirely disarticulated remains; (2) under-represented thoracic segments; and, (3) disarticulated sclerites that are commonly fragmented. It is also noteworthy that trilobites in this taphofacies commonly occur with tabulate and rugose corals as well as spiriferids, rhynchonellids and strophomenids that were also identified

(text continued on page 279) 


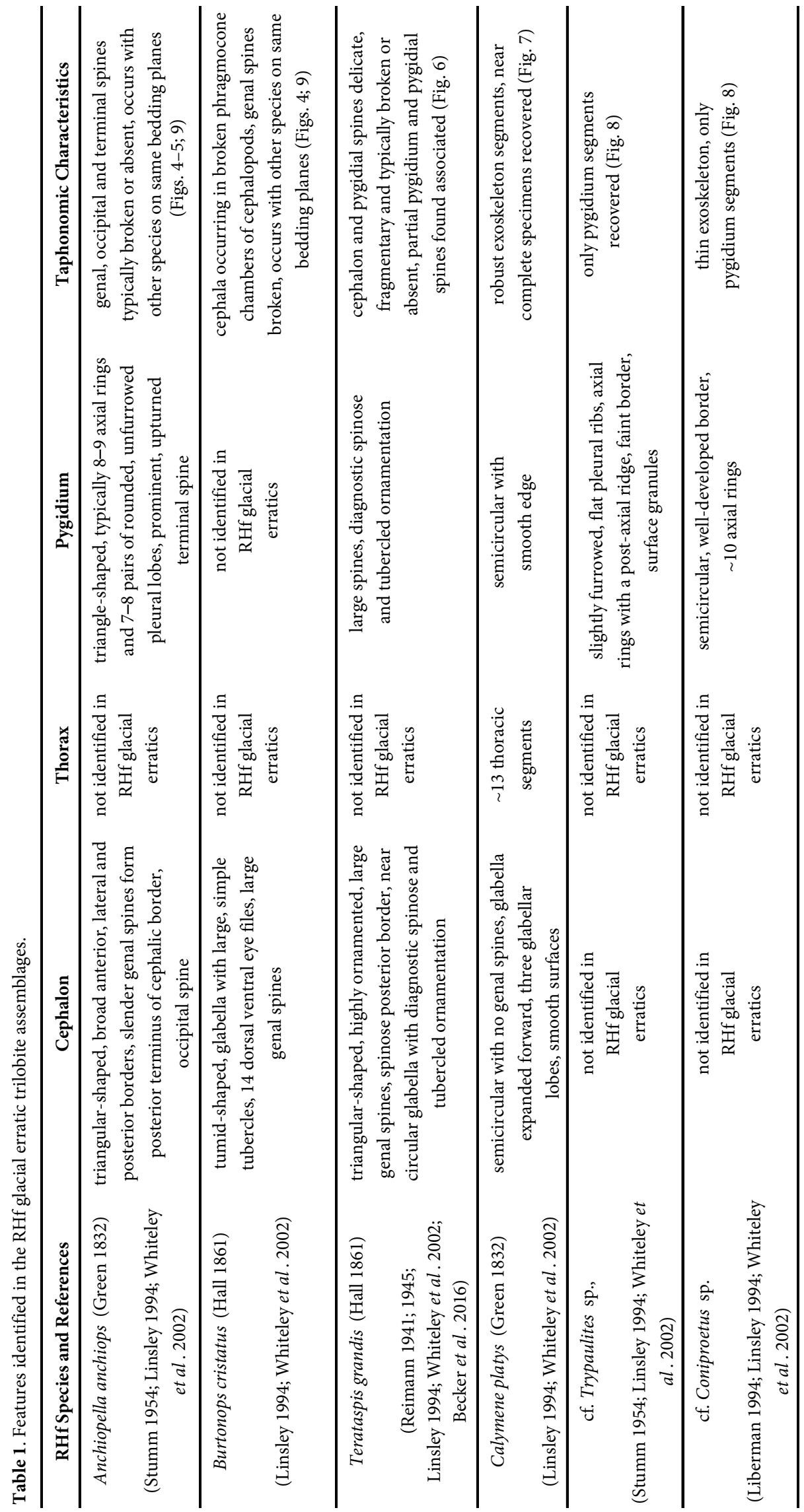



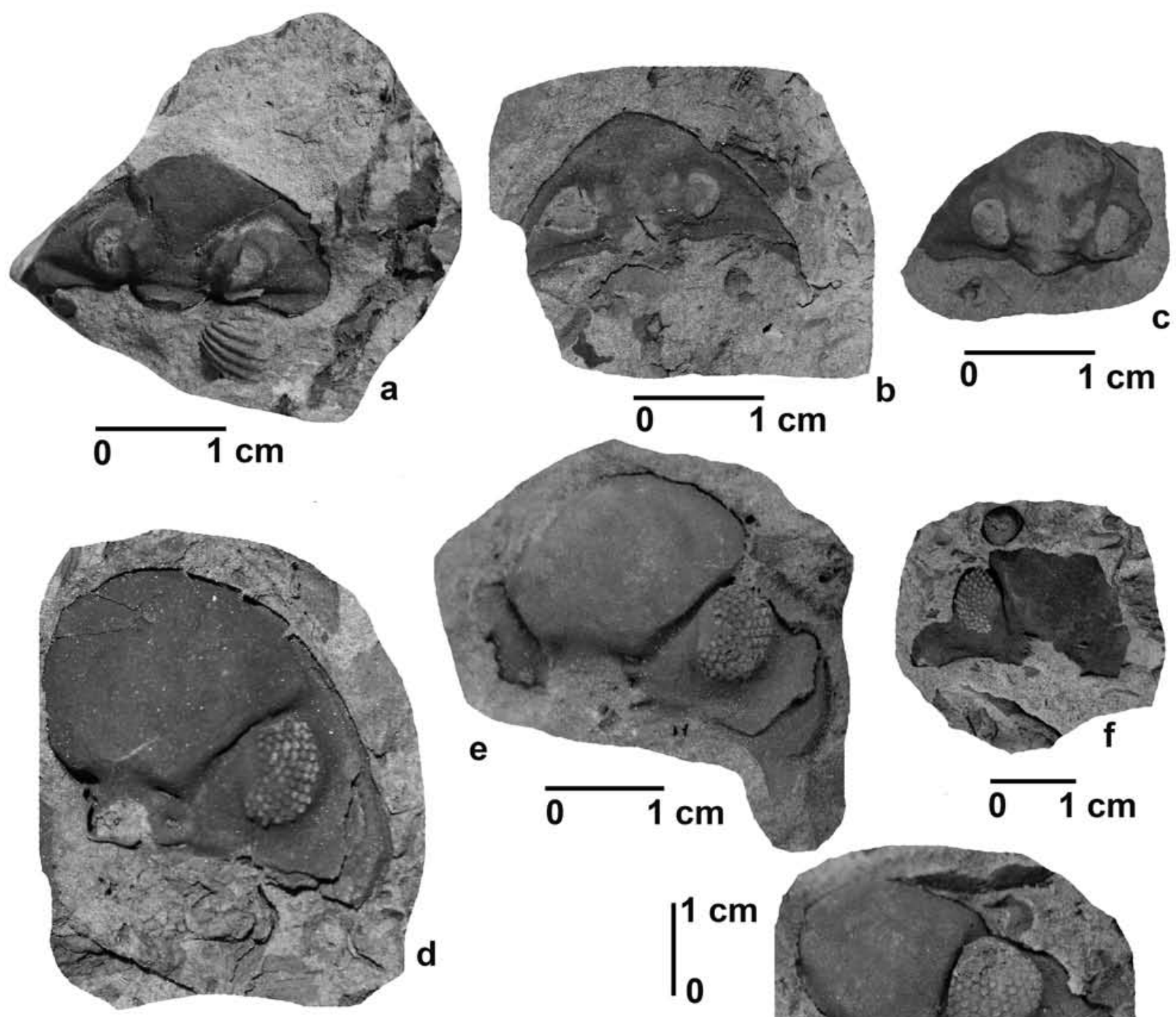

\section{.}
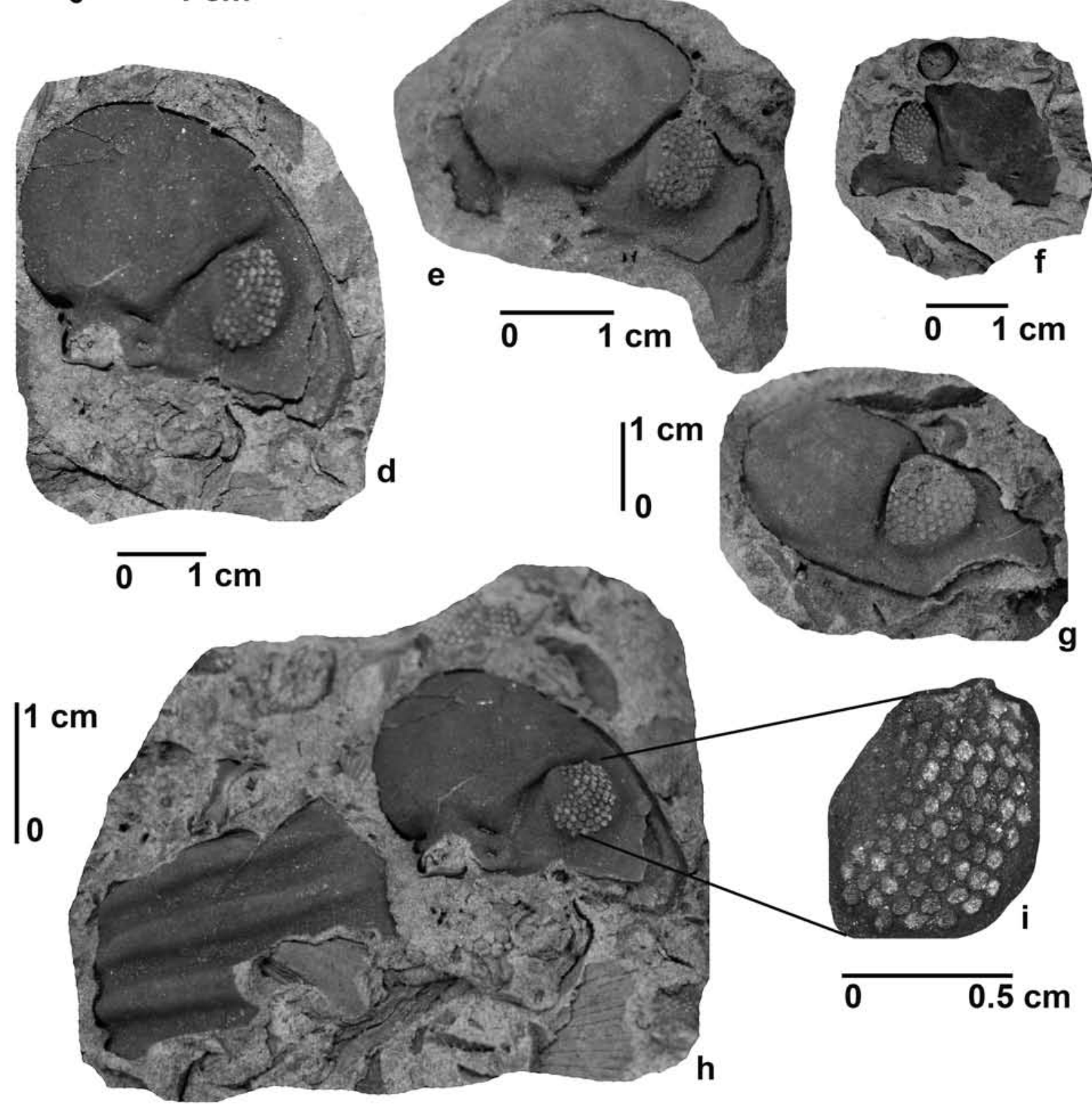

Figure 4. Anchiopella anchiops and Burtonops cristatus cephala casts from RHf glacial erratics. (a-c): Anchiopella anchiops and (d-i): Burtonops cristatus. Note distinct shape of glabellas and diagnostic fourteen rows of eye lenses seen in (i). 

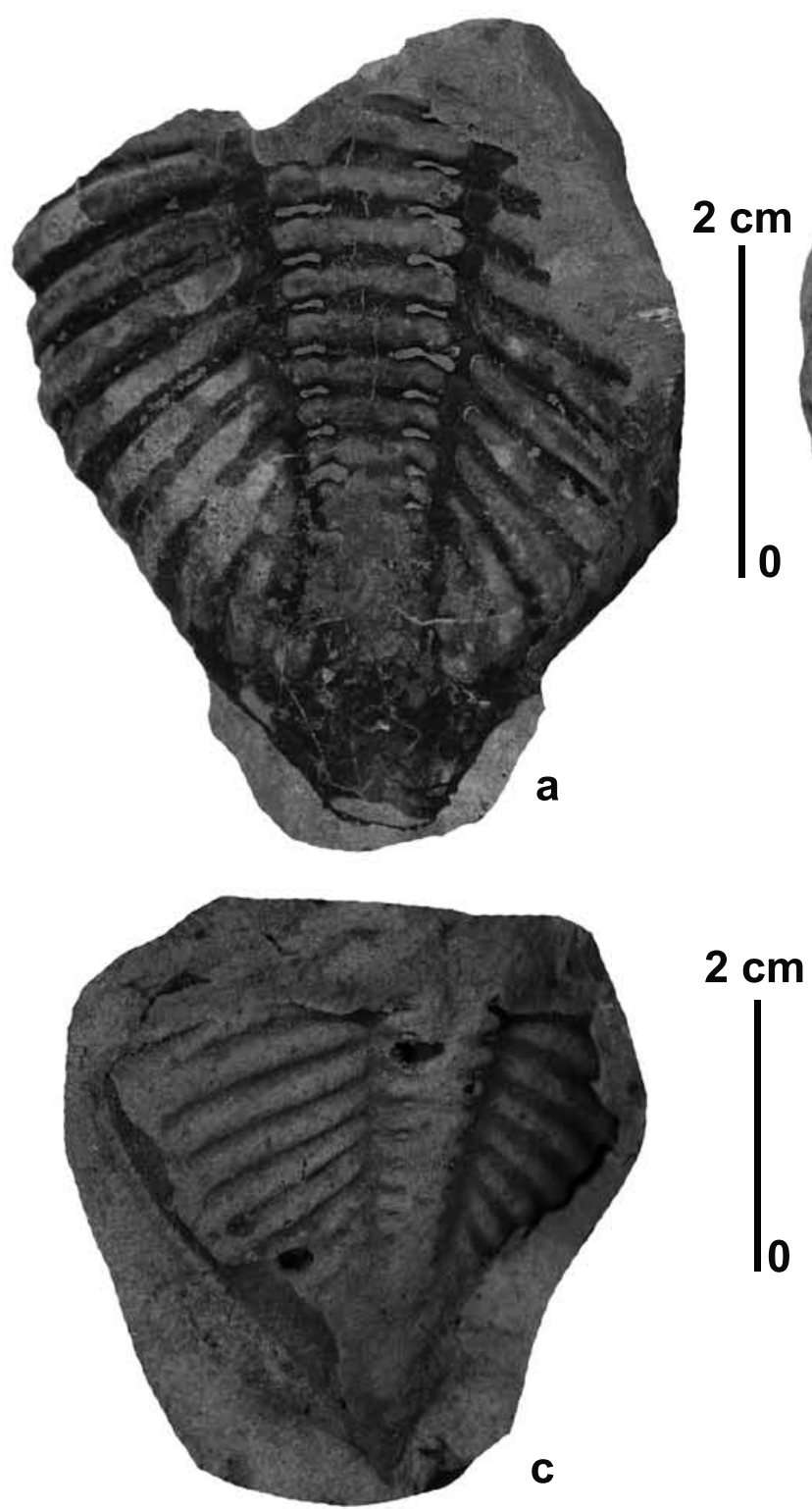

$2 \mathrm{~cm}$
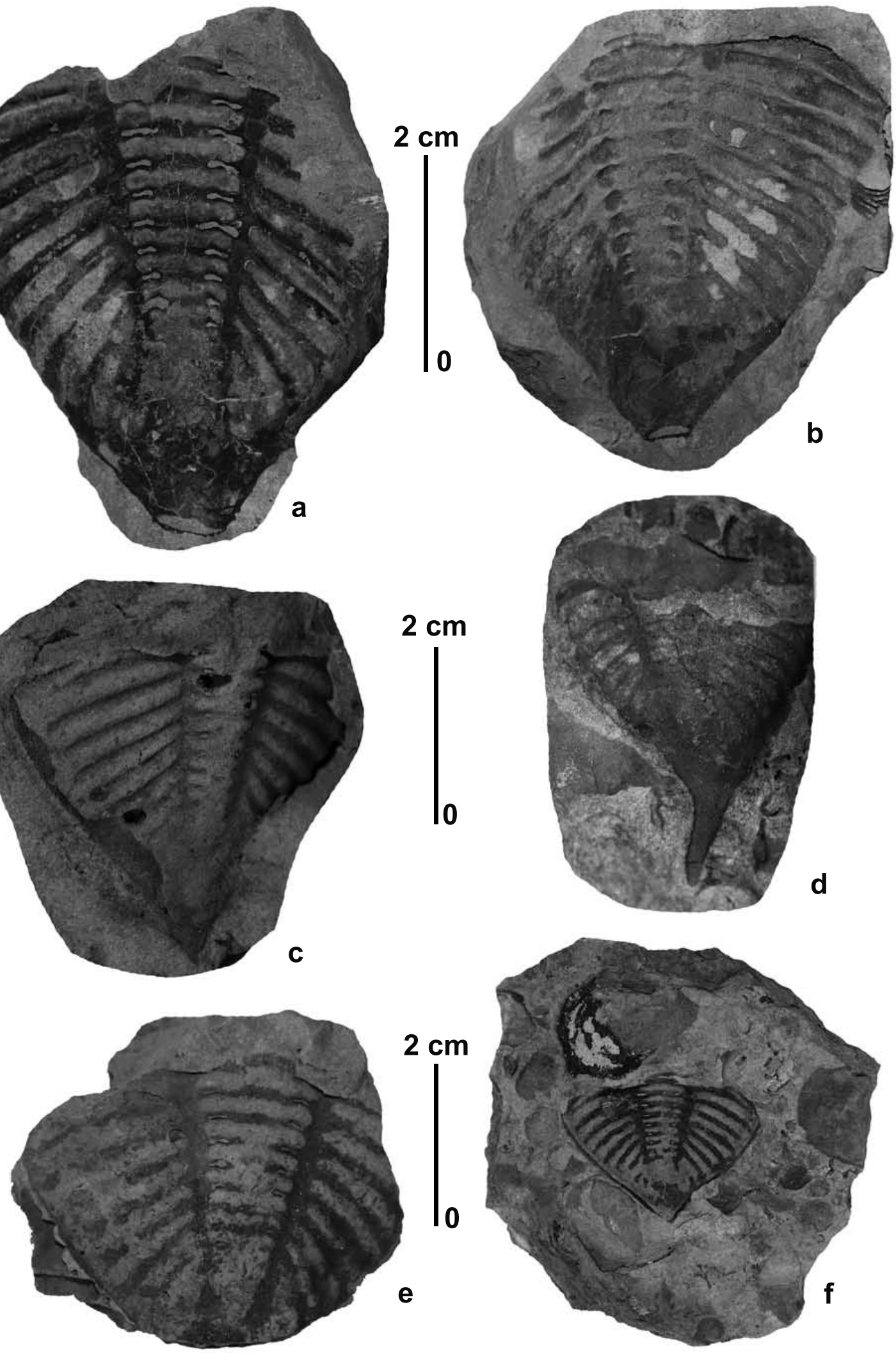

Figure 5. Anchiopella anchiops pygidia casts (a, c-d) and mold (b) from RHf glacial erratics. Note diagnostic terminal spine in (d) indicated by arrow. 

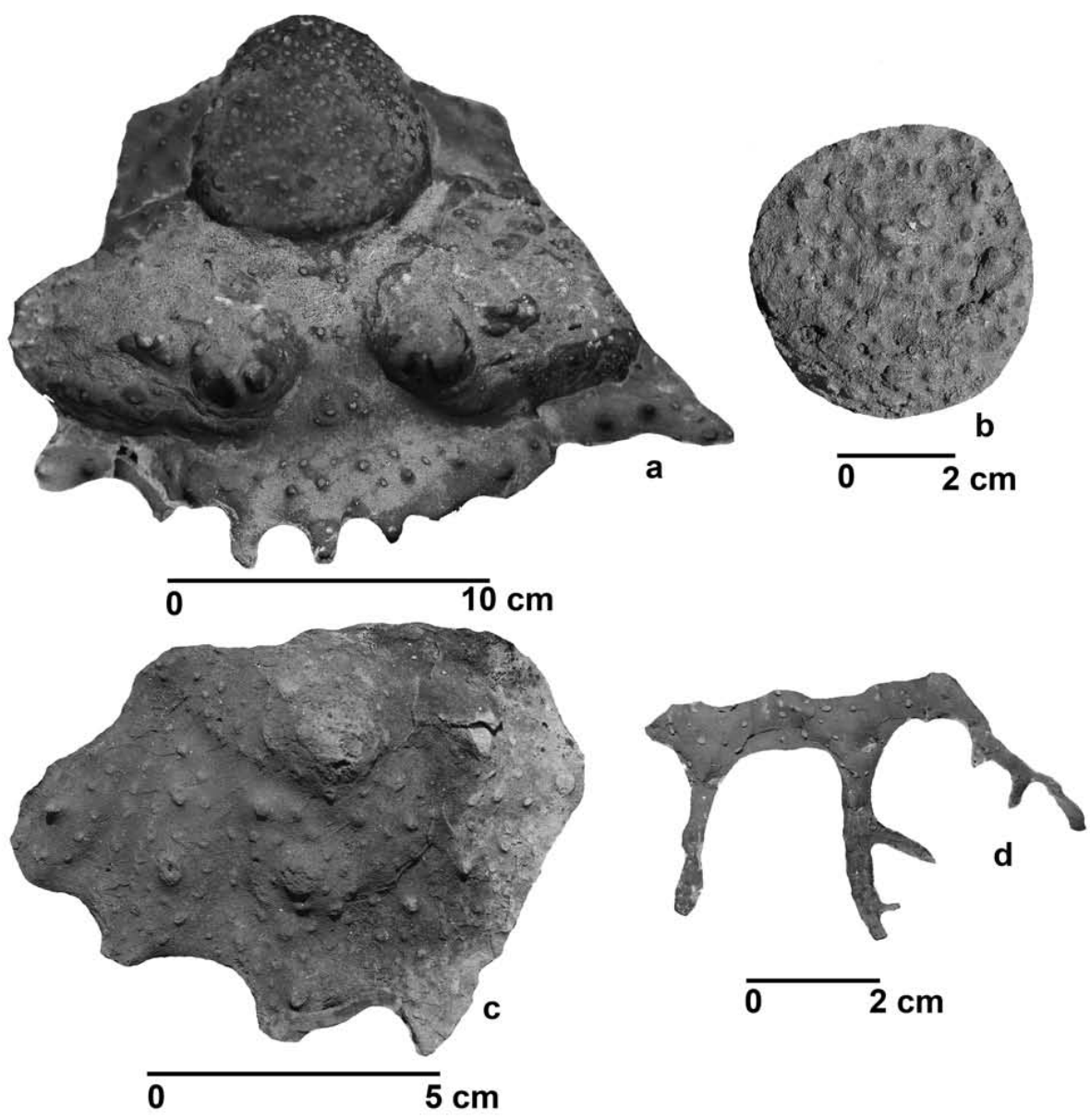

Figure 6. Terataspis grandis cephalon $(\mathrm{a}-$ mold), glabella $(\mathrm{b}-$ cast $)$, pygidium $(\mathrm{c}-$ cast $)$ and pygidium spines $(\mathrm{d}-$ cast $)$ from RHf glacial erratics. Note distinct spinose and node ornamentations. Specimens (c-d) were not articulated, but recovered adjacent to one another on the same RHf glacial erratic.
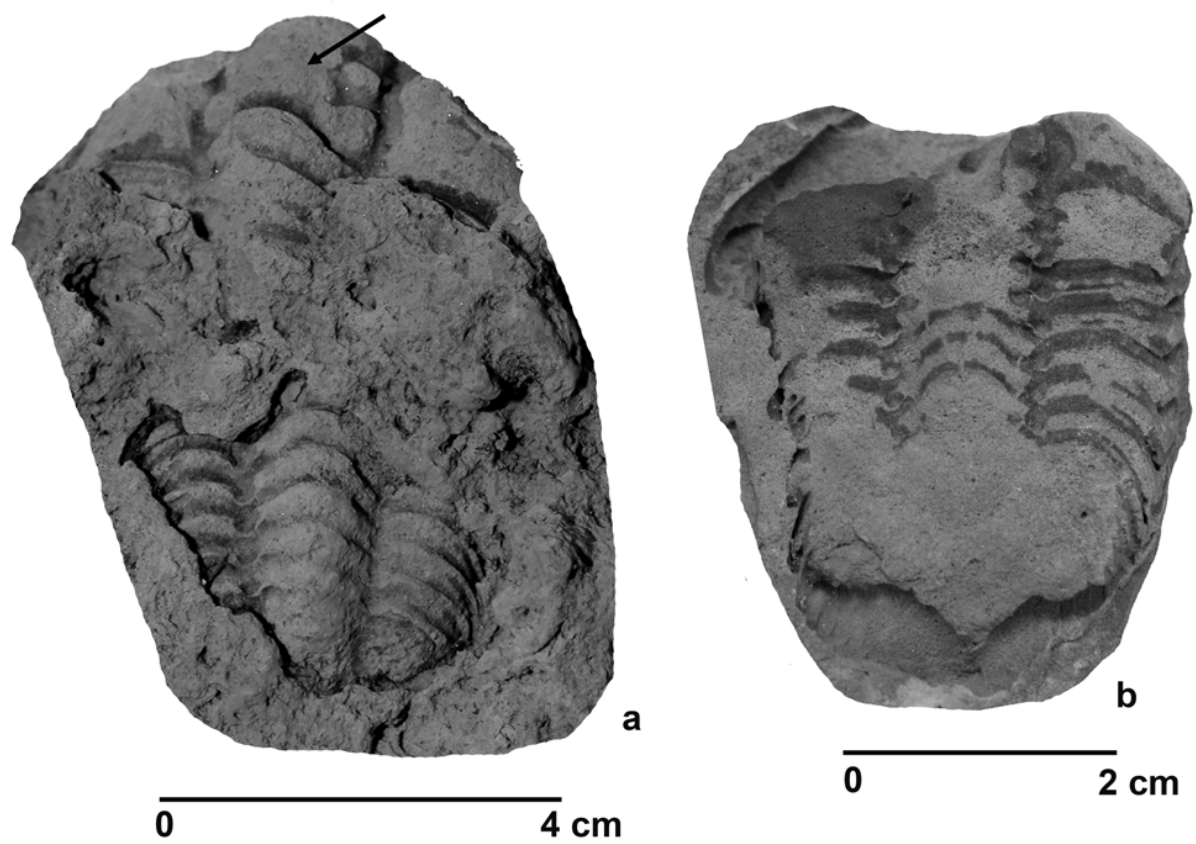

Figure 7. Near complete Calymene platys trilobite casts (a-b) from glacial erratics of the RHf. Note distinct forward expanding glabella in (a) indicated by arrow. 

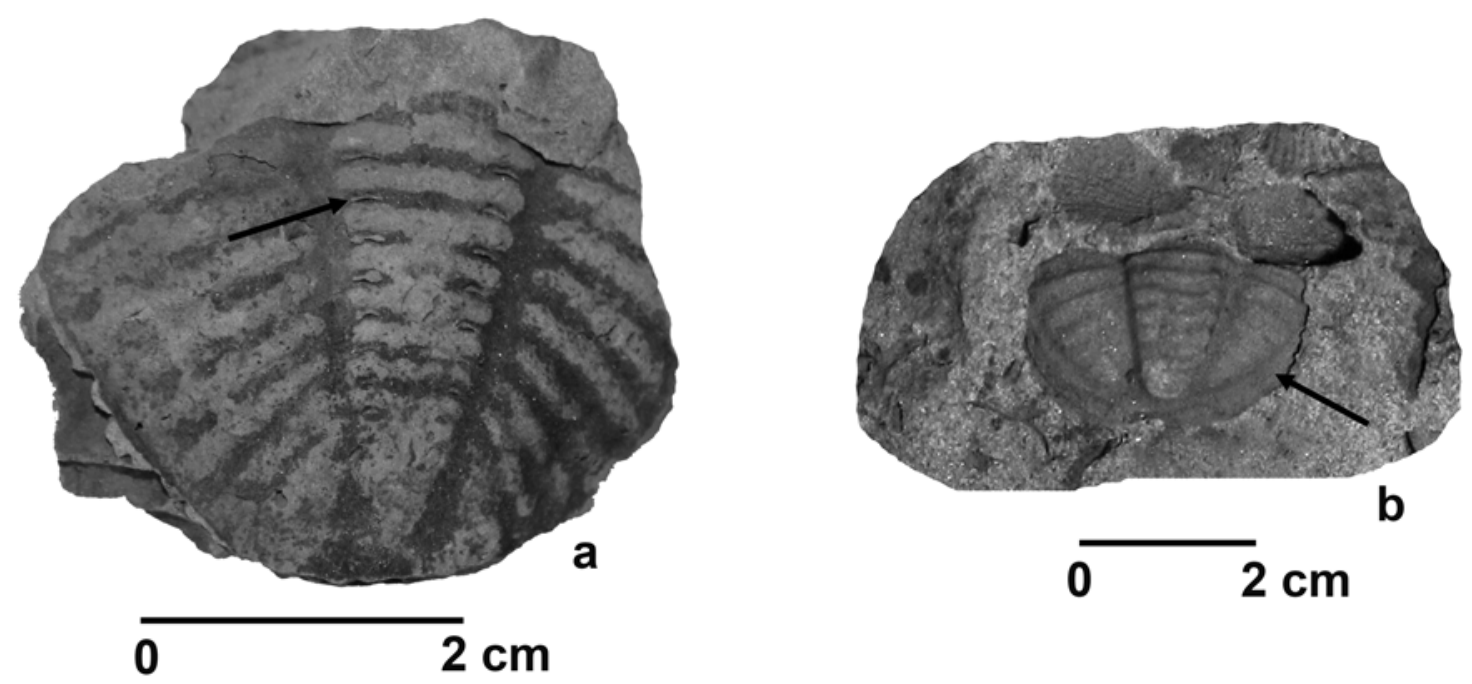

Figure 8. Pygidia casts of (a) cf. Trypaulites sp. and (b) cf. Coniproetus sp. from RHf glacial erratics. Note flat pleural ribs in (a) and pygidial border in (b) indicated by arrows.

in RHf glacial erratics by Becker and Bartholomew (2013). Speyer and Brett (1986) further indicated that taphofacies 1A represented environmental conditions near normal wave base with current agitation, multiple reworking events and lag accumulation.

Additional support for similarities between taphofacies $1 \mathrm{~A}$ of Speyer and Brett (1986) and a lag deposit origin for trilobites and other invertebrates occurring in the RHf glacial erratics can be seen in Figs. 9-10. Along more extensive fossiliferous bedding planes: (1) cephala and pygidia from two different species, Anchiopella anchiops and Burtonops cristatus are preserved adjacent to one another (Figs. 9d-e); and (2) cephala and pygidia of indeterminate species of trilobite are oriented in multiple directions with sclerite orientations as convex up and convex down (Figs. 10a-b). In other examples: (1) broken phragmocone chambers of cephalopods are filled with sediment and cephala from phacopids (Figs. 9a-c); and, (2) large cephalopods that show preferred orientations occur, along with indeterminate species of trilobites (Figs. 10ac). Furthermore, lag deposits in New York also commonly preserve Calymene platys and associated body segments due to a robust exoskeleton (Whiteley et al. 2002). During this study, two nearly complete specimens of this trilobite species were recovered in RHf glacial erratics (Figs. 7a-b). None of the other trilobites in our assemblage are preserved as whole specimens.

In some instances, the exoskeletons of invertebrates in RHf glacial erratics may have formed temporary shelly hardgrounds, as indicated by: (1) borings and bryozoan encrustation on brachiopod valves (Figs. 10d-e); and (2) algal accumulations that have encrusted brachiopod valves (Fig. 10f). Brett (1995) indicated that these types of hardgrounds and skeletal accumulations are typical at bedding surfaces and discontinuities during sea level rise and sediment starvation. These stratigraphic and paleontological characteristics are also seen in the RHf of the Clarksville region and in RHf glacial erratics from the Lower Hudson Valley and northern New Jersey Piedmont (Figs. 2-3).

\section{SEQUENCE STRATIGRAPHY AND RHF LAG DEPOS- IT FORMATION}

The original sequence-stratigraphic framework for the transition between the Schoharie and Onondaga formations was compiled by Brett and Ver Straeten (1994) and in subsequent publications, including Ver Straeten (1996; 2007) and Brett et al. (2009; 2011). In eastern New York, the transition between the Saugerties Member of the Schoharie Formation and Edgecliff Member of the Onondaga Formation is gradational and relatively conformable (e.g., Goldring and Flower 1942; Oliver 1956; Johnsen and Southard 1962; Brett and Ver Straeten 1994; Ver Straeten 1996; 2007). However, in central and western New York, Ver Straeten (1996) identified the sub-Edgecliff Member unconformity, which locally becomes amalgamated with the pre-Schoharie and Wallbridge unconformities. It is noteworthy that in the present study the localized RHf containing the trilobites and other invertebrates occurs within the transition between eastern and central New York (Fig. 1).

According to Ver Straeten (2007, fig. 19), the contact between the uppermost Schoharie and lowermost Onondaga formations, as well as the Saugerties and Edgecliff members, delineates the third-order eustatic sealevel sequence boundary between the Emsian Cycle 5 and Eifelian Cycle 1 (Fig. 2). This contact also occurs along the maximum regressive surface of Acadian Tectophase 1, as identified by Ver Straeten (2007), and along a regional 

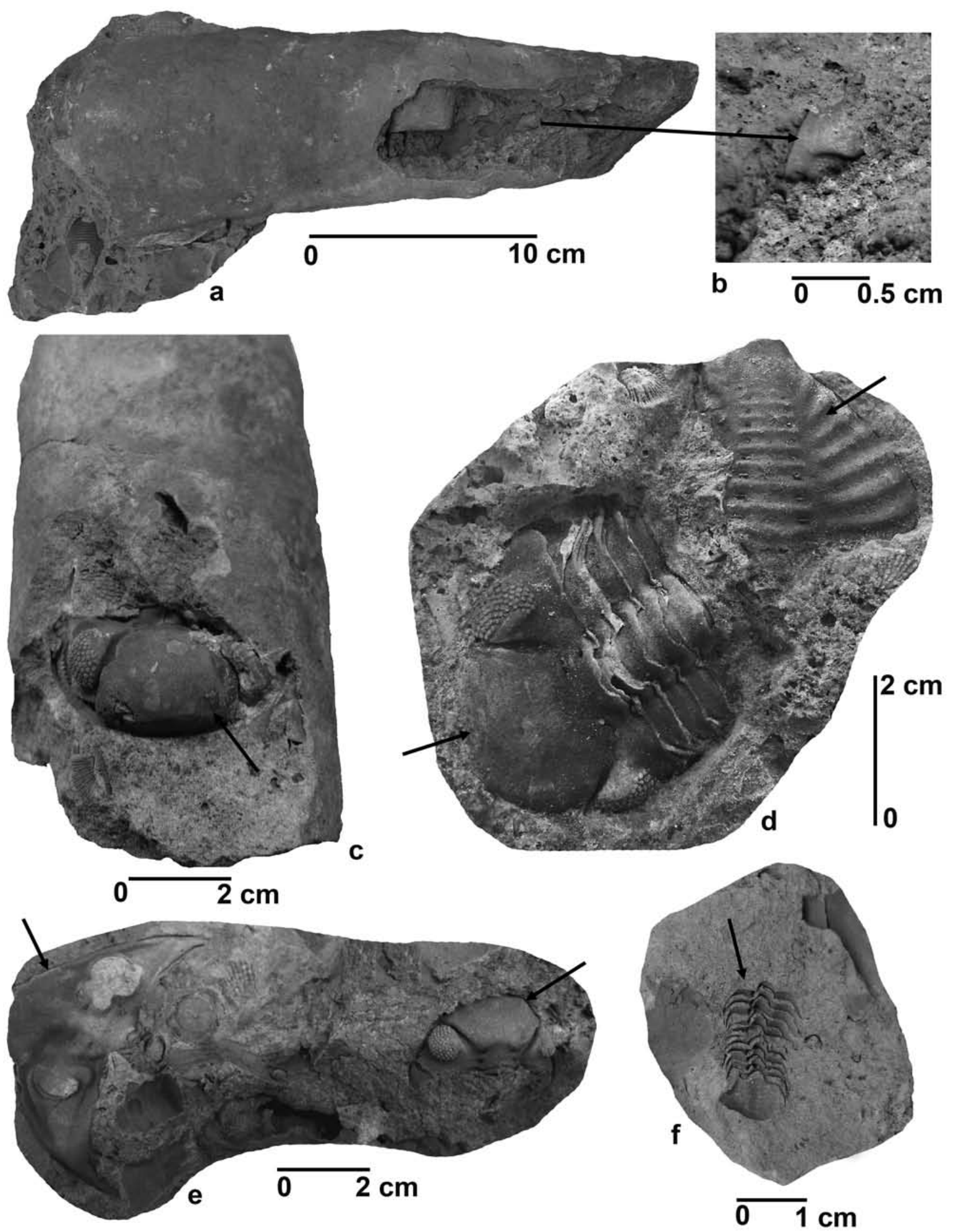

Figure 9. Taphonomic and paleontological features seen in RHf glacial erratics. (a) Cephalon of Burtonops cristatus preserved in the broken phragmocone chambers of cephalopod. (b) Close up of Burtonops cristatus preserved in the broken phragmocone chambers seen in (a) and indicated by arrow. (c) Cephalon of Burtonops cristatus preserved in broken phragmocone chambers of cephalopod of indicated by arrow. (d-e) Cephala and pygidia from Anchiopella anchiops and Burtonops cristatus preserved on same bedding planes indicated by arrows. (f) Disarticulated thorax region from an indeterminate trilobite species indicated by arrow. 

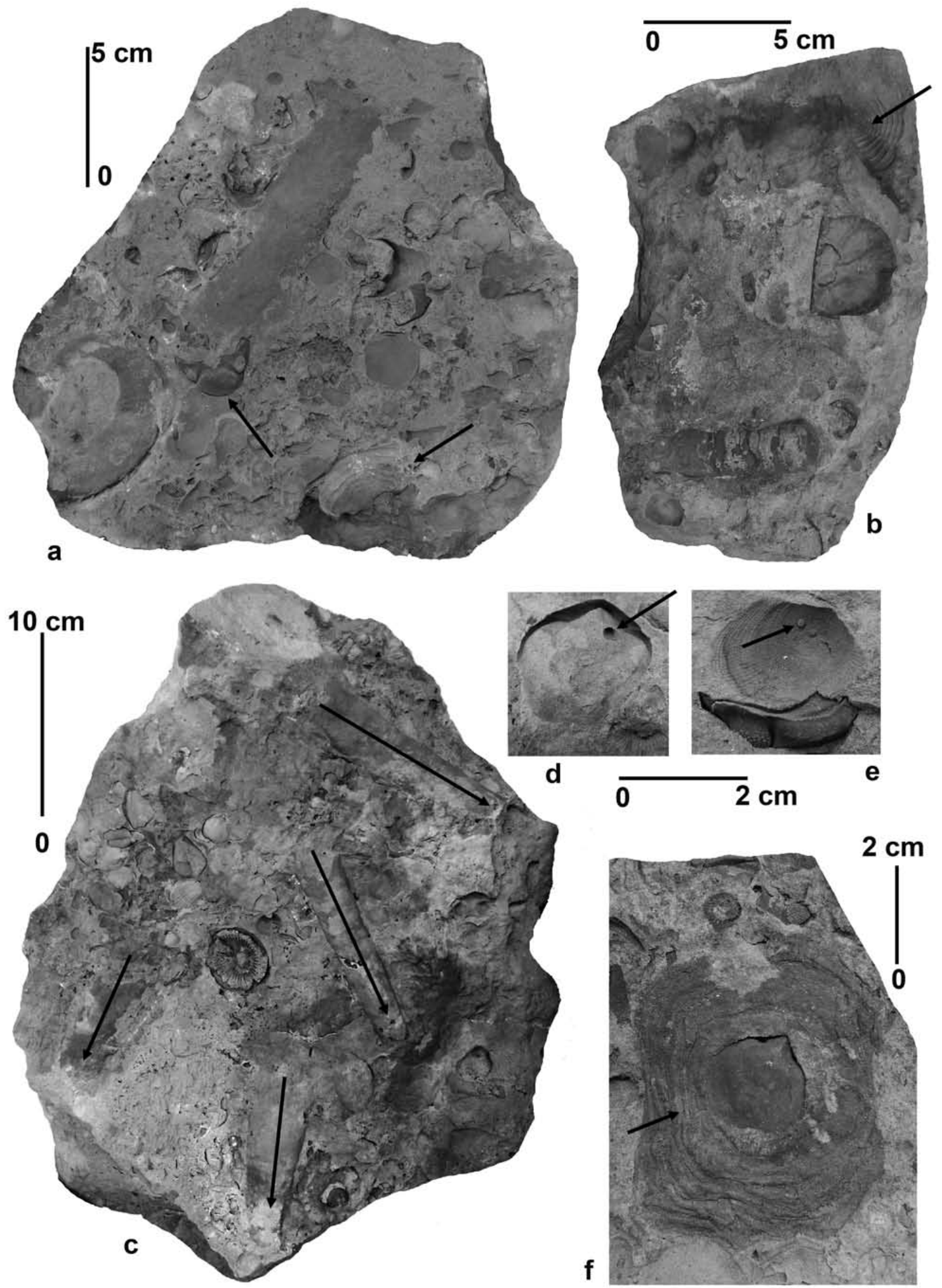

Figure 10. Taphonomic and paleontological features seen in RHf glacial erratics. (a-b) Cephalon and pygidium from indeterminate species of trilobites with sclerite orientations as convex up and convex down indicated by arrows. (c) Cephalopods with hydrodynamically orientated body chambers as indicated by arrows. (d) Boring on brachiopod valve near hinge indicated by arrow. (e) Bryozoan growth on interior of brachiopod valve indicated by arrow and deposited on an indeterminate species of trilobite cephalon. (f) Algal accumulation encrusting brachiopod valve indicated by arrow. 
unconformity in New York (Brett et al. 2011). Based on conodont biostratigraphy, this contact also coincides approximately with the uppermost Emsian and thus the boundary between the Lower and Middle Devonian (Kendall et al. 1983; Brett et al. 2009). According to Brett et al. (2009) and based on the estimates of Kaufman (2006), the Schoharie Formation was deposited over an interval of about 5 to 8 million years.

Based on the sequence stratigraphy and taphonomy discussed above, we interpret the RHf lag deposit to have accumulated initially during third-order sea-level regression in Emsian Cycle 5 of Ver Straeten (2007), and as part of a shallowing-upward cycle bounded below and above by the sub-Aquetuck and sub-Edgecliff unconformities. Trilobites and other invertebrate fauna would have been concentrated during exhumation and reburial events where localized wave base was capable of eroding into the shallow shelf platform in this area of eastern New York. Subsequent third-order sea-level transgression in Eifelian Cycle 1 of Ver Straeten (2007) would have resulted in preservation of the sandy limestone beds and the RHf lag deposit containing the trilobites and other invertebrates. The role of third-order sea-level cyclicity in the formation of this localized lag deposit is further reinforced by: (1) the sharp, erosional contact and distinct lithological change between the 1-m-thick RHf and underlying Saugerties Member (Fig. $2)$; (2) the fragmentary nature and random orientations of trilobites and other invertebrates (Figs. 4-10); and (3) hydrodynamic orientation of the larger cephalopods and inclusion of trilobite cephala in broken phragmocone chambers of cephalopods (Figs. 9a-c).

Lag deposits similar to the RHf have also been identified in the Upper Ordovician Trenton Group and Middle Devonian Hamilton Group of New York (Brett 1995; Brett and Baird 1986; 1996). Basal transgressive beds commonly show shell concentrations with long-term time averaging, mineralization (including pyrite casts) above the maximum flooding surface, and concentration of nautiloids directly above an erosional disconformity (see Brett 1995). These additional basal transgressive and taphonomic features are also preserved in the RHf and suggest that this localized facies may in fact belong to the basalmost Edgecliff Member of the Onondaga Formation and initial transgression during Eifelian Cycle 1 of Ver Straeten (2007).

In the Helderberg Mountains region of New York, the Devonian outcrop belt bends sharply to the west near Albany, with the Taconic Mountains to the east and the Low Mountains and Western Hills of the Adirondack Mountains to the north. We interpret the discontinuous nature of the RHf in eastern New York as reflecting this shift in overall strike and dip along the Helderberg Escarpment and as representing a shallower-water shelf setting relative to other outcrops of the Saugerties Member of the Schoharie Formation seen in Kingston, Highland Mills and Port Jervis. The localized concentration and abundance of trilobites and other invertebrate fossils in the RHf reflects these bathymetric controls on wave and current activity across this shallower-water setting. To the southeast and west of the RHf outcrop belt, the notable absence of fossil concentration and the gradational contact between the Schoharie and Onondaga formations indicates that deposition took place well below normal wave base and within deeper parts of the basin. Widespread changes in water depth in equivalent strata across the Appalachian Basin are also observed across the Schoharie-Onondaga transition and are related to an uplifted peripheral bulge in Acadian Tectophase 1, as identified by Ver Straeten (2007).

It is also significant that the RHf may have originally extended to the east to the Hudson River Gorge but if so was removed by glaciation of the Hudson-Champlain Lobe of the Laurentide Ice Sheet (see Sirkin and Bokuniewicz 2006). RHf glacial erratics containing the trilobites and other invertebrates described in this report, as well as those of Becker and Bartholomew (2013) and Becker et al. (2016), were likely part of this original eastward extension of the outcrop belt, which has been subsequently eroded, transported and deposited as far south as the northern New Jersey Piedmont.

\section{ACKNOWLEDGEMENTS}

This research was supported in part by Center for Research and Assigned Release Times grants from William Paterson University to M. Becker. Reviews of C. Brett, R. Fensome and C. Ver Straeten improved an earlier version of this manuscript. Field and laboratory assistance was provided by B. Danielson, C. Gocklin, O. Pacella, D. Pagano and R. Scimeca.

\section{REFERENCES}

Becker, M. and Bartholomew, A. 2013. Rickard Hill facies of the Schoharie Formation (Lower Devonian) glacial erratics from the Preakness Formation (Lower Jurassic) of High Mountain, Passaic County, New Jersey. Atlantic Geology, 49, pp. 194-203.

Becker, M., Maisch, H., and Bartholomew, A. 2016. Pleistocene ice flow direction indicated by Terataspis grandis (trilobite) bearing erratics from the Rickard Hill facies of the Saugerties Member of the Schoharie Formation (Lower Devonian). Northeastern Geosciences, 34, pp. 7-11.

Brembs, R., Heinemann, A., Scimeca, R., Maisch, H., Becker, M., and Bartholomew, A. 2015. Cephalopod diversity in the Lower Devonian Schoharie Formation: a unique opportunity for reassessment of diversity from glacial erratics. Geological Society of America Abstracts with Programs, 47, p. 138.

Brett, C. 1995. Sequence stratigraphy, biostratigraphy, and taphonomy in shallow marine environments. Palaios 10, pp. 597-616. https://doi.org/10.2307/3515097 
Brett, C. and Baird, G. 1986. Symmetrical and upward shallowing cycles in the Middle Devonian of New York State and their implications for the punctuated aggradational cyclehypothesis. Paleoceanography, 1,pp. 431-445. https://doi.org/10.1029/PA001i004p00431

Brett, C. and Baird, G. 1996. Middle Devonian sedimentary cycles and sequences in the northern Appalachian Basin. In Paleozoic sequence stratigraphy; views from the North American craton. Edited by B. Witzke and J., Day. Geological Society of America Special Paper 306, pp. 213-241. https://doi.org/10.1130/0-8137-2306-X.213

Brett, C. and Ver Straeten, C. 1994. Stratigraphy and facies relationships of the Eifelian Onondaga Limestone (Middle Devonian) in western and west central New York State. In Fieldtrip Guidebook, New York State Geological Association 68th Annual Meeting. Edited by C. Brett and J. Scatterday, pp. 221-270.

Brett, C., Ivany, L., Bartholomew, A., DeSantis, M., and Baird, G. 2009. Devonian ecological-evolutionary subunits in the Appalachian Basin: a revision and a test of persistence and discreteness. Geological Society, London, Special Publications, 314, pp. 7-36. https:// doi.org/10.1144/SP314.2

Brett, C., Baird, G., Bartholomew, A., DeSantis, M., and Ver Straeten, C. 2011. Sequence stratigraphy and a revised sea-level curve for the Middle Devonian of eastern North America. Palaeogeography, Palaeoclimatology, Palaeoecology, 304, pp. 21-53. https://doi. org/10.1016/j.palaeo.2010.10.009

Cooper, M. and Mylroie, J. 2015. Cave and karst systems of the world: glaciation and speleogenesis, interpretations from the northeastern United States. Springer, Heidelberg, $142 \mathrm{p}$.

Couri, G., Malgieri, T., and Bartholomew, A. 2011. Rediscovery of the "Trilobite Bed" of the Port Jervis Formation (Upper Lochovian-Lower Pragian?) at Trilobite Mountain, Port Jervis, New York. Geologic Society of America Abstracts with Programs, 43, p. 428.

Epstein, A., Epstein, J., Spink, W., and Jennings, D. 1967. Upper Silurian and Lower Devonian stratigraphy of northeastern Pennsylvania, New Jersey, and southeasternmost New York. United States Survey Bulletin 1243, $74 \mathrm{p}$.

Goldring, W. and Flower, R. 1942. Restudy of the Schoharie and Esopus formations in New York State. American Journal of Science, 240, pp. 673-694. https://doi. org/10.2475/ajs.240.10.673

Green, J. 1832. Synopsis of the trilobites of North America. American Journal of Geology and Natural History, 1, pp. 558-560.

Hall, J. 1861. Descriptions of new species of fossil from the Upper Helderberg, Hamilton and Chemung Groups; with observations on previously described species. Annual Report of the Regents of the University of the State of New York on the Condition of the Cabinet of Natural History, Albany, New York, 14, pp. 99-109.
Johnsen, J. and Southard, J. 1962. The Schoharie Formation in southeastern New York. In Fieldtrip Guidebook, New York State Geological Association 34th Annual Meeting. Edited by W. Valentine, pp. 7-19.

Kaufmann, B. 2006. Calibrating the Devonian time scale: a synthesis of $\mathrm{U}-\mathrm{Pb}$ ID-TIMS ages and conodont stratigraphy. Earth-Science Reviews, 76, pp. 175-190. https://doi.org/10.1016/j.earscirev.2006.01.001

Kendall, G., Johnson, J., Brown, J., and Klapper, G. 1983. Stratigraphy and facies across Lower Devonian Middle Devonian boundary, central Nevada. American Association of Petroleum Geologists Bulletin, 67, pp. 2199-2207.

Lieberman, B. 1994. Evolution of the trilobite subfamily Proetinae and the origin, evolutionary affinity, and extinction of the Middle Devonian proetid fauna of eastern North America. Bulletin of the American Museum of Natural History, 223, $176 \mathrm{p}$.

Linsley, D. 1994. Devonian paleontology of New York, Paleontological Research Institution Special Publication, 21, $472 \mathrm{p}$.

Oliver, W. 1956. Stratigraphy of the Onondaga Limestone in eastern New York. Geological Society of America Bulletin, 67, pp. 1441-1474. https://doi. org/10.1130/0016-7606(1956)67[1441:SOTOLI]2.0. $\mathrm{CO} ; 2$

Reimann, I. 1941. A new restoration of Terataspis. Bulletin of the Buffalo Society of Natural Sciences, 17, pp. 3956.

Reimann, I. 1945. The thorax of Terataspis. Journal of Paleontology, 19, pp. 69-71.

Shimer, H. 1905. Upper Siluric and Lower Devonic faunas of Trilobite Mountain, Orange County, New York. New York State Museum, Bulletin 80, Paleontology 10, Report of the State Paleontologist 1903, pp. 175269.

Sirkin, L. and Bokuniewicz, H. 2006. The Hudson River Valley: geological history, landforms, and resources. In The Hudson River Estuary. Edited by J. Levinton and J. Waldman. Cambridge University Press, pp. 13-23. https://doi.org/10.1017/CBO9780511550539.004

Speyer, S. and Brett, C. 1986. Trilobite taphonomy and Middle Devonian taphofacies. Palaios, 1, pp. 312-327. https://doi.org/10.2307/3514694

Stanford, S. 2003. Surficial geology of the Paterson quadrangle, Passaic, Bergen, and Essex counties, New Jersey. New Jersey Geologic Survey Open File Map 54, scale 1:24 000 .

Stone, B., Stanford, S., and Witte, R. 2002. Surficial geologic map of northern New Jersey. U.S. Geological Survey Miscellaneous Investigations Map I-2540-C, scale 1:100 000 .

Stumm, E. 1954. Lower Devonian phacopid trilobites from Michigan, southwestern Ontario, and the Ohio Valley. Contributions from the Museum of Paleontology, University of Michigan, 11, pp. 201-221. 
Ver Straeten, C. 1996. Stratigraphic synthesis and tectonic and sequence stratigraphic framework, upper Lower and Middle Devonian, northern and central Appalachian Basin. Unpublished Ph. D. thesis, University of Rochester, Rochester, New York, 800 p.

Ver Straeten, C. 2007. Basinwide stratigraphic synthesis and sequence stratigraphy, upper Pragian, Emsian and Eifelian stages (Lower to Middle Devonian), Appalachian Basin. Geological Society, London, Special Publications, 278, pp. 39-81. https://doi. org/10.1144/SP278.3

Ver Straeten, C. and Brett, C. 2006. Pragian to Eifelian Strata (middle Lower to lower Middle Devonian), northern Appalachian Basin - stratigraphic nomenclatural changes. Northeastern Geology and Environmental Sciences, 28, pp. 80-95.

Weller, S. 1903. The Paleozoic faunas. New Jersey Geologic Survey Report on Paleontology, JL Murphy Publishing Company, printers, 3, $462 \mathrm{p}$.
Whiteley, T., Kloc, G. and Brett, C. 2002. Trilobites of New York: an illustrated guide. Ithaca, New York, Cornell University Press, 380 p.

Whitfield, R. and Parsons, S. 1897. Note on the hypostome of Lichas (Terataspis) grandis Hall. Bulletin of the American Museum of Natural History, 9, pp. 45-46.

Woodward, H. 1873. On a new trilobite from the Cape of Good Hope. Quarterly Journal of the Geological Society of London, 29, pp. 31-33. https://doi.org/10.1144/GSL. JGS.1873.029.01-02.09

Younger, Z., Bartholomew, A., Becker, M., and Maisch, H. 2016. Brachiopods from the Rickard Hill facies of the Saugerties Member of the Schoharie Formation (Lower Devonian), Helderberg Mountains, New York: a case study from glacial erratics. Geologic Society of America Abstracts with Programs, 48, pp. 61-14.

Editorial responsibility: Robert A. Fensome 